The European fame of Sir William MacCormac as a British surgeon almost equals that of Lord Lister. Honours were showered upon him by the Governments and learned societies of foreign States, and his friends included some of the most famous continental surgeons of modern times. Stromeyer, Esmarch, Langenbeck, Coler, Billroth, Mundy, Larrey, Pozzi and many others knew and admired his work and valued his friendship, while his commanding presence was recognised and acclaimed in all assemblies of military surgeons, wherever he went. Indeed it may be said of him that no man in this country kept up his connection with colleagues abroad as he did: His hospitality to them and to all his friends was proverbial.

MacCormac's minor contributions to the literature of his profession are chiefly found in the St. Thomas's Hospital reports and in the medical journals. His larger works, in addition to articles on "Gunshot Wounds" in Heath's "Surgery," "Diseases of the Bones and Joints" in Quain's "Dictionary of Medicine", and "Hernia" in Treves" "System of Surgery," are "Antiseptic Surgery," the development of an address delivered at St. Thomas's Hospital, published in 1880 and translated into French and. Russian, and "Surgical Operations," the first part of which, the ligatures of arteries, was published in 1885 , and the second, operations on joints and nerves, in 1889. With the exception, however, of his "Notes and Recollections of an Ambulance Surgeon," none of his writings are likely to have the same historical interest as his father's work on consumption, and it can scarcely be claimed that the success of his career was due to any exercise of a power for scientific investigation, although he undoubtedly possessed that power. He was skilful as an operator, lucid and loved as a teacher; but it was his wisdom in counsel, the sanity of his judgment, the common sense of his oratory, rather than any marked advances made by him in the science and art of surgery, that gained him the unique distinction of being elected president of the Royal College of Surgeons four times in succession. He was knighted in I88I for his services as general secretary of the Seventh International Medical Congress in London, and was created a baronet on the occasion of the Queen's Jubilee in 1897. He was appointed a K.C.V.O. in 1898 and a K.C.B. in February last after his return from South Africa. He was appointed Surgeon-in-Ordinary to H.R.H, the Prince of Wales and Honorary Sergeant-Surgeon to the King on his Majesty's accession to the Throne. The last year of his life was somewhat saddened by the controversies that arose in consequence of his outspoken support of the Army Medical Service during the war. He felt bitterly how much the country had been misled by those who decried the work of the Army medical officers and who knew little of war and still less of the surgical possibilities of war.

Sir William MacCormac married, in 1861, Miss Charteris, of Belfast, but had no family. Lady MacCormac, who was his life-long companion and accompanied him wherever he went, survives him.

The funeral of Sir William MacCormac took place on Monday, the first part of the funeral service being observed at the church of St. Peter, Vere Street. His Majesty the King was represented by General Godfrey Clerk. The French and German Embassies in London were represented, respectively, by M. E. Daeschner and Major Count von Bredow. The French Consul-General in London was also present. The council of the Royal College of Surgeons was represented by Mr. J. Langton, Mr. H. G. Howse, Mr. T. Bryant, Mr. A. Willett, Mr. R. Harrison, Mr. H. T. Butlin and Mr. W. W. Cheyne. Prof. C. Stewart, conservator of the museum, was also present, as well as many others connected with the Royal College of Surgeons and the profession of surgery.
The Royal College of Physicians was represented by Sir W. S. Church (president), Sir Dyce Duckworth (treasurer) and Dr. E. Liveing (registrar). Of St. Thomas's Hospital, with which Sir W: MacCormac had been so long connected, there were many representatives. Among other institutions represented were the French Hospital, the Army Medical Department, Medical Department of the Navy, the Italian Hospital, Queen Charlotte's Hospital, the University of London, the British Museum and the British Association. Among many others present were Lord Lister, Sir William Broadbent, Sir Norman Lockyer, Sir Thomas Smith, Sir Lauder Brunton, Jr. T. Seymour Tuke, Dr. P. H. Pye-Smith, Major-General Sir Owen Tudor Burne, Mr. Andrew Clark, Sir J. and Lady Fayrer, Dr. and Mrs. D'Arcy Power, Sir F. and Lady Semon, Lady Dyce Duckworth, Sir A. S. Wells, Sir S. Wilks, Sir J. W. Williams and Sir James Blyth.

\section{THOMAS MEEHAN.}

THE eminently successful life of Thomas Meehan, distinguished as a gardener, a botanist and a citizen, closed on November I9. Mr. Meehan was born in London in March I826, and received what little schooling he had in the Isle of Wight, where his family had settled. Leaving school at an early age, and displaying a marked aptitude for gardening, he was employed under his father in the gardens of Colonel Francis Vernon Harcourt, at St. Clare, near Ryde. When only fourteen he succeeded in raising the first hybrid Fuchsia, St. Clare, and in appreciation of a paper which he published on Rubus was elected, when only nineteen, a member of the Wernerian Society. After holding various gardening appointments he entered the Royal Botanic Gardens, Kew, in 1846, on the recommendations of Dr. Bromfield and Prof. C. C. Babington. At Kew, where he stayed a little more than two years, he made the acquaintance of Berthold Seemann, with whom he was a candidate for the appointment of botanist to the Herald expedition. On leaving Kew he became head-gardener to the Earl of Shrewsbury at Alton Towers, a post which, owing to his religious opinions, he was soon obliged to relinquish. Though offered tempting inducements to remain in his native country, Meehan determined to make America his home, and reached Philadelphia in March 1848 .

His career there opened in the humble position of a nursery labourer. But advancement quickly followed. He obtained employment in the famous Bartram Gardens of Philadelphia, and in 1853 , with remarkably little capital, established a nursery business of his own, which, in conjunction with his sons, he continued to the end of his life. He was a voluminous writer on horticultural and botanical subjects. He founded the well-known Meehan's Monthly, and half a century ago published his "Handbook of Ornamental Trees." In I 878-79 appeared "The Native Flowers and Ferns of the United States," a handsome illustrated work in two large octavo volumes. His botanical papers contributed to various scientific journals, and chiefly to the Proceedings of the Academy of Natural Sciences of Philadelphia, number considerably more than a hundred. Enthusiastic in all his undertakings, Meehan became a leading member of the Philadelphia Academy, of which he was vice-president for more than twenty years; a representative of his ward in the Common Council, and a member of the local school board; while his botanical attainments secured for him the proud position of Botanist to the Pennsylvania State Board of Agriculture.

Reviewing his life's story, the heroic toil, the splendid energy, the brilliant success achieved in spite of all obstacles, a tribute of praise such as this, and from a far wider world, is due to the memory of Thomas Meehan.

S. A. Skan. No. [676, vOL. 65] 